\title{
Standardizing Procedure in a Combination System of Supervised Study, Varying Scope of Work, and Weighted Credit
}

\section{W. H. Hughes}

To cite this article: W. H. Hughes (1920) Standardizing Procedure in a Combination System of Supervised Study, Varying Scope of Work, and Weighted Credit, The Journal of Educational Research, 2:2, 547-556, DOI: 10.1080/00220671.1920.10879086

To link to this article: http://dx.doi.org/10.1080/00220671.1920.10879086

Published online: 15 Dec 2014.

Submit your article to this journal $\sqsubset$

ai

View related articles $\square$

Citing articles: 1 View citing articles $\longleftarrow$ 


\title{
STANDARDIZING PROCEDURE IN A COMBINATION SYSTEM OF SUPERVISED STUDY, VARYING SCOPE OF WORK, AND WEIGHTED CREDIT
}

\author{
W. H. HUGHES \\ Principal, Riverview Union High School, Antioch, California
}

The purpose of this paper is to set forth some of the methods employed in the Riverview Union High School in administering a combination plan which takes into account the variations of natural capacities and acquired interests, and at the same time accords credit toward graduation in proportion to individual achievement. The more general features of the plan are included in the accompanying chart taken from our Teachers' and Students' Handbook.

Provisions of the general scheme summarized.-The more outstanding provisions of the system may be briefly summarized as follows: (1) a specific statement in each subject concerning the scope and quality of work which a student of average ability should be able to accomplish when working up to his full capacity, i.e., the general requirements for the medium grade, $\mathrm{B}$, which entitles the student to 1.0 unit of credit; (2) a careful enumeration in each subject of the characteristics of excellent work entitling the student to the A grade which carries with it 1.1 units credit; (3) a general statement in each subject relative to the many possibilities for extra scope of work which the student of superior ability, interest, initiative, and application may do along the lines of his special interests in satisfaction of the extra requirements for the AA grade which entitles him to 1.2 units credit; (4) special encouragement and direction for the student of extraordinary ability, interest, application, and achievement in doing an original piece of work relative to the subject for which he may be entitled to the AAA grade and 1.3 units credit; (5) provisions for diminished credit for inferior work; and (6) a full hour class period the first half of which is given to recitation and discussion and the last half to supervised study, enabling the teacher not only to give attention to the backward student in bringing him as nearly as 
possible up to the medium standard but to direct and supervise the efforts of the more capable student along the lines of his special interests. It will be noted that the plan is not merely one for

EXPLANATION OF MARKING AND CREDITING SYSTEM

(From the Teachers' and Sludents' Handbook)

\begin{tabular}{|c|c|c|c|}
\hline Marks & $\begin{array}{l}\text { Meaning of These Marks and Sugges- } \\
\text { tions for Improvement }\end{array}$ & $\begin{array}{l}\text { Crediting } \\
\text { Value for Two } \\
\text { Semester } \\
\text { Subject }\end{array}$ & $\begin{array}{l}\text { Approximate } \\
\text { Number of } \\
\text { Students in } 100 \\
\text { Receiving } \\
\text { This Mark }\end{array}$ \\
\hline AAA & $\begin{array}{l}\text { The AAA mark is reserved for the stu- } \\
\text { dent or students of extraordinary ability, } \\
\text { interest, initiative, and application. In } \\
\text { addition to meeting the requirements } \\
\text { for all lower marks, the AAA student } \\
\text { must do a piece of original work in which } \\
\text { he shows his ability to collect informa- } \\
\text { tion from a variety of sources and to } \\
\text { organize it into a well-written paper of } \\
\text { reasonable length Or, if the subject } \\
\text { is non-academic in nature, the extra } \\
\text { piece of original work may differ from } \\
\text { that suggested above but, in any case, } \\
\text { must be approved by the head of the } \\
\text { department and by the principal of the } \\
\text { bigh school. One or possibly two stu- } \\
\text { dents in one hundred may reasonably be } \\
\text { expected to do the work required for } \\
\text { this mark. }\end{array}$ & 1.3 & 1 or 2 \\
\hline AA & $\begin{array}{l}\text { The AA mark is reserved for students of } \\
\text { superior ability, interest, initiative, and } \\
\text { application. In addition to meeting the } \\
\text { requirements for all lower marks in a } \\
\text { given subject, the AA student must } \\
\text { cover an extra scope of subject matter } \\
\text { which is to be indicated by the teacher. } \\
\text { This extra scope should be rich in prac- } \\
\text { tical applications of the subject and } \\
\text { should lead the student into a system- } \\
\text { atic use of supplementary materials such } \\
\text { as reference books, encyclopedias, } \\
\text { periodicals, government report, etc. } \\
\text { The nature of this extra scope should, } \\
\text { so far as posible, be determined by the } \\
\text { special interests of the student. Ap- } \\
\text { proximately, four students in one hun- } \\
\text { dred should be successful in doing the } \\
\text { work required for this mark. }\end{array}$ & 1.2 & 4 \\
\hline A & $\begin{array}{l}\text { The A mark is used to denote excellency } \\
\text { in meeting the general requirements of a } \\
\text { given subject. In a group of one hun- } \\
\text { dred students there should be approxi- } \\
\text { mately twenty receiving the A mark. } \\
\text { This twenty should be better than the } \\
\text { seventy-five who receive lower marks; } \\
\text { but hardly so good as the five best stu- } \\
\text { dents in the hundred. The student re- } \\
\text { ceiving the A mark should show ability, } \\
\text { interest, self-reliance, and application } \\
\text { superior to the average student. His } \\
\text { recitations should be excellent; his writ- } \\
\text { ten work, accurate, neat and legible; his } \\
\text { attendance regular; and his attitude to- } \\
\text { ward school commendable. Nothing in } \\
\text { the explanation of this mark should be } \\
\text { considered to preclude assignments of } \\
\text { desirable supplementary work. }\end{array}$ & 1.1 & 20 \\
\hline
\end{tabular}




\section{MARKING AND CREDITING SYSTEM (Continued)}

\begin{tabular}{|c|c|c|c|}
\hline Marks & $\begin{array}{l}\text { Meaning of These Marks and Sug- } \\
\text { gestions for Improvement }\end{array}$ & $\begin{array}{l}\text { Crediting } \\
\text { Value for Two } \\
\text { Semester } \\
\text { Subject }\end{array}$ & $\begin{array}{l}\text { Approximate } \\
\text { Number of } \\
\text { Students in } 100 \\
\text { Receiving } \\
\text { This Mark }\end{array}$ \\
\hline B & $\begin{array}{l}\text { The B mark is used to denote average } \\
\text { ability and attainment in a given sub- } \\
\text { ject. In a group of one hundred stu- } \\
\text { dents a p p o x i m a te ly fifty may be } \\
\text { expected to receive this mark. This } \\
\text { means that there are twenty-five stu- } \\
\text { dents better and twenty-6ve poorer } \\
\text { than this medium group of fifty. To } \\
\text { receive the B mark a student must } \\
\text { satisfy the general requirements of the } \\
\text { subject with respect to the specific as- } \\
\text { signments, oral and written work, exer- } \\
\text { cises, note books, translations, book } \\
\text { reviews tests, etc. All work must be } \\
\text { reasonably prompt, neat and accurate. } \\
\text { Good attention in class and proper use } \\
\text { of time in school hours are taken into } \\
\text { consideration in the assignment of this } \\
\text { mark. }\end{array}$ & 1.0 & 50 \\
\hline C & $\begin{array}{l}\text { The C mark is used to indicate ability } \\
\text { and attainment somewhat below the } \\
\text { medium. In a group of one hundred stu- } \\
\text { dents, approximately seventy-five will } \\
\text { do a quality of work better, and five will } \\
\text { do a quality of work poorer, than that } \\
\text { represented by the mark. The quality } \\
\text { of work entitling the students to this } \\
\text { mark is just as far below the average as } \\
\text { the quality of work for the A mark is } \\
\text { above the average. For the marks C } \\
\text { and B the scope of work is practically } \\
\text { the same. The C student wishing to } \\
\text { improve the quality of his work should } \\
\text { follow the suggestions given under A } \\
\text { and B. }\end{array}$ & .9 & 20 \\
\hline D & $\begin{array}{l}\text { The D mark is used to represent the next } \\
\text { lower step in the quality of work accom- } \\
\text { plished. It is as much inferior to C as C } \\
\text { is inferior to B. In a group of one hun- } \\
\text { dred students approximately four may } \\
\text { be expected to do work of this grade and } \\
\text { character. The D student who wishes } \\
\text { to improve the quality of his work should } \\
\text { follow the suggestions given under B and } \\
\text { A. }\end{array}$ & .8 & 4 \\
\hline $\mathrm{E}$ & $\begin{array}{l}\text { The } \mathrm{E} \text { mark is used to indicate the poor- } \\
\text { est quality of work which may be ac- } \\
\text { cepted for credit toward graduation. It } \\
\text { means that the student is either inferior } \\
\text { in his ability or that he is not making the } \\
\text { proper use of his time. The } E \text { students } \\
\text { should try to improve the quality of their } \\
\text { work by following the suggestions given } \\
\text { under A and B. }\end{array}$ & .7 & 1 \\
\hline $\mathbf{F}$ & $\begin{array}{l}\text { The } \mathrm{F} \text { mark is used to indicate absolute } \\
\text { failure. }\end{array}$ & .0 & $?$ \\
\hline
\end{tabular}

giving "extra credit for extra quality" of work accomplished. Quality is important but is not in itself sufficient. Extra scope and 
extraordinary kind of work are to be encouraged if the student of superior ability is to receive justice.

Slandardizing teachers' procedure.-One of the first steps in the administration of such a system is to make teachers familiar with the fundamental principles of variation. Although, on every hand, they are confronted with the general facts of variation, they need to have brought to their attention many specific cases of exact measurement and distribution. Illustrative cases for this purpose may easily be found in various books of statistical method, in the studies of Thorndike on individual differences, and in many articles of educational and psychological journals. Incidentally, the results obtained from various intelligence tests in our own high school still further corroborate the theory that capacities are distributed remarkably in accordance with the symmetrical curve.

The next move on the part of the administrator is to make clear the approximate distribution of marks in the adopted system if it is to be at all scientific. "We would laugh at a government," says Professor Max Meyer, "requiring each citizen to pay an income tax, but failing to state what percentage of the income is to be paid. We should likewise laugh at a school administration telling its teachers to report some A grades, some B grades, some $\mathrm{C}$ grades and so on. Each teacher, in reporting, would then unwittingly grade, not his pupils so much, but rather himself, his own notion of what ought to be done. That is, one would report that according to his conviction a teacher ought to report only, say, six percent A grades; another would express his conviction that a teacher ought to report, say, twelve percent A grades; a third would grade himself as believing in eighteen percent A grades; and so on to the most liberally grading teacher. But the school administration does not want its teachers thus to grade themselves. It wants them to grade their pupils, so that one may tell who is the best kind of scholar, who a less good scholar, and who a very poor scholar."

We have therefore taken the precaution not only to work out rather definitely the specific requirements for the different marks in our system but to indicate approximately the percent of students who ordinarily should be expected to receive these marks respectively. The $\mathbf{B}$ grade in our system is taken as the starting 
point. (See definition in chart given above.) It is what the student of medium ability should earn when working up to his full capacity in school time and spending half an hour daily on each subject outside of classrooms. Since the student carries four subjects regularly, the teacher is cautioned against requiring more for the B standard than can reasonably be accomplished in half an hour of home study. (It is generally understood that on the average two hours of home study are necessary for satisfying our general requirements.) According to our definition of the B mark approximately fifty students in one hundred (in addition to those securing $\mathrm{A}, \mathrm{AA}$, and $\mathrm{AAA}$ ) should earn it.

The B standards having been indicated, it is equally important to make clear the general requirements for the higher marks. The teacher is occasionally reminded that the A mark is used to denote excellency in meeting the general requirements of a given subject. (See statement concerning this mark in the chart at beginning of this article.) According to our defin tion of this mark approximately two students should earn it for every five who receive the $\mathrm{B}$ mark. This number, however, may vary; but any marked variation receives the attention of the principal. The AA mark, it will be noted, stands for more than mere excellency in meeting the general requirements of a subject. It is reserved for students of superior ability, interest, initiative, application, and achievement who master an extra scope of subject matter or work in a given study. The extra scope must be approved by both principal and teacher. This provision serves as a check to teachers who might otherwise be inclined to assign too many AA marks. It helps also to standardize the amount and kind of work required for the mark. According to our definition of the AA mark, approximately one student should earn it for every five who receive the A mark. Any wide variation from this ratio requires explanation. In the same way, the AAA mark is reserved for the student or students of extraordinary ability, interest, application, initiative, and achievement. As stated above the student must offer a piece of individual work extending through the semester (or year) in addition to satisfying the requirements for all lower marks. This extra piece of work must be approved by teacher and principal. This method of approval serves as a check on the system and assures the maintenance of high standards. According 
to our definition of the AAA mark approximately one or two students in a hundred should be able to secure it. All conditions being normal, a too large percent of the higher marks indicates the desirability of raising the standards.

Another important factor in the standardization of our marking system is a monthly comparison of the distribution curves of the different departments with the general curve adopted for our system. Our teachers know, however, that there are certain acceptable reasons for departure from the theoretical curve: (1) an unusually large percent of students in a given class may have come from cultured homes; (2) an unusually large percent may have come from uncultured homes; (3) students may be of unusual maturity of mind; (4) the teacher may be extraordinarily skillful in effective instruction; (5) the class may be inadequately prepared for the subject; (6) the class may be exceptionally well prepared for the subject; (7) there may be an unusual percent of superior or of inferior students. On the other hand, teachers know equally well that there are unacceplable reasons for departure from the theoretical curve of distribution: (1) low marks because of attempting to cover too much ground; (2) high marks because of meager requirements; (3) low marks based on inadequate data; (4) high marks to give an impression of efficiency; (5) high marks to curry favor with students and influential parents; (6) high marks to avoid criticism of troublesome parents; (7) low marks because of one's own disgruntled disposition; (8) high marks because of the student's "effort" although it has been unproductive. With so many possibilities for variation from a normal curve of distribution, it is evident that a system of weighted credits needs careful supervision in order to insure the maintenance of high standards.

When conspicuous variations from the adopted curve of distribution are in evidence it is, of course, the business of the administrator to ascertain if possible whether such variations are justifiable or remediable. In this connection we have found the results of intelligence testing of considerable value. It is needless to say that if a student has been found far below the average in mental capacity and is carrying away the highest marks in a particular class or classes, his case is one suitable for investigation. In like manner, if the student of superior ability as indicated by the 
mental tests, is receiving marks considerably below the average, his case also needs attention. It is not always and necessarily found, however, that the marks of this bright student are too low. But the fact that there is a discrepancy between his capacities and his school standing may direct the attention of teachers and principal in such a way as to improve his work and eliminate the discrepancy. At the present stage of imperfection in mental testing, however, the principal should not depend exclusively upon the results of a single type of mental test. An average high score or an average low score for a number of the best-known mental tests is more dependable than a high score or a low score in any one of them.

As a mechanical means of administering the marking and crediting system, the accompanying form of report card has been devised and found useful. ${ }^{1}$ The red lines are a constant reminder that B is a medium grade. Such a card makes it easy for the principal or supervisor quickly to get a general impression as to the comparative levels of grading of the different departments. With this card containing in graphical form the complete record of a student in all subjects for any month, semester, or full year, the principal can easily note any tendency of teachers to vary from the adopted standards. The key to the marking system included in every report card is also a checking device.

\section{MONTHLY REPORT}

To Parent and Student:

The purpose of this report is to indicate the relative standing of the student, with respect to the poorest and the best. The student's grade is indicated by a check $[V]$ mark under the appropriate letter. Any check under B between a pair of red lines means good, average work and achievement; a check to the right of the red lines means poorer than the average for students in general; a check to the left of the red lines means better than the average. In order to do creditable work, every student will find it necessary to spend at least two hours a day in study outside the class rooms.

W. H. Hughes, Principal

${ }^{1}$ The card actually used carries an abbreviation of the "Explanation of Marking and Crediting System" given on page 548. In order to draw attention to the "B" rating as the average mark, the lines inclosing this letter are printed in red. The card is in the form of a four-page folder. The second and third pages are shown here. The first and fourth pages are reserved for the name of the school and of the pupil and for the parent's signatures.-EDITor. 
The effectiveness of the foregoing methods may be seen in the following distribution of marks for the first semester of the school year 1919-1920. The entries are in percents.

\begin{tabular}{|c|c|c|c|c|c|c|c|c|}
\hline Months & AAA & AA & A & B & $\mathrm{C}$ & $\mathrm{D}$ & E & $\mathrm{F}$ \\
\hline September. & 0 & 0.5 & 10 & 49 & 27.5 & 9 & 2.9 & 1 \\
\hline October..... & 0 & 4.0 & 16 & 48 & 26 & 5 & 1.0 & 0 \\
\hline November.... & 0 & 3.9 & 20.1 & 44.3 & 24.7 & 5.6 & 0.6 & 0.4 \\
\hline December... & 0 & 4.1 & 19.7 & 43.5 & 23.0 & 8.3 & 0.8 & 0.4 \\
\hline January............. & 0 & 2.0 & 17.8 & 42.2 & 26.0 & 9.5 & 1.8 & 0.5 \\
\hline Semester.......... & 0 & 3.9 & 19.5 & 43.3 & 24.8 & 6.6 & 1.8 & 0.0 \\
\hline
\end{tabular}

With respect to supervised study, which is a part of our combination scheme, it is more difficult to standardize procedure because of the varied nature of the different subjects and the individual methods of teachers. Occasionally, however, we have found it profitable to call the attention of teachers to various possible sorts of classroom activities. Recently our teachers examined their own methods for an entire week indicating on a chart prepared for the purpose the approximate percent of class time devoted to each of the following activities: (1) assignment of work; (2) instruction in best methods of study, either general or specific; (3) recitation taking the form of quiz and consisting principally of questions and answers based on the general requirements in the regular text; (4) special reports by students on supplementary work related to the regular assignments, i.e., making the classroom a "clearing house" for information; (5) cooperative development lesson during which all students are simultaneously engaged under the leadership of the teacher in working up a new portion of the subject; (6) individual work by students either with supplementary books and materials or with laboratory and shop apparatus; (7) supervised study of general assignments and direction of extrascope activities; (8) lecture by instructor; and (9) any other class activity employed by the teacher. The results of this study showed that our teachers are spending not more than one-fourth of the class hour in recitation, but at least three-fourths of the hour in the other forms of activity.

The attitude of our faculty and student body toward the system is most favorable. Almost without exception, our 
teachers are enthusiastic over the plan and its possibilities. Many of us believe that the students of superior capacities are now accomplishing at least twice as much as formerly. We are equally confident that the work of every type of student has been improved. Never before have our teachers seen students so eager for supplementary work. Under the old system few of us believed that a freshman would, of his own accord, read over two thousand pages of supplementary material in a semester subject. Several freshmen under our present system have done this and at least one has read nearly three thousand pages. In every subject, students are "reaching out after more." These are some of the many reasons why practically all of our teachers are advocates of the present combination system of supervised study, varying scope of work, and crediting in proportion to individual achievement. 